\title{
Yhteisö ja ryhmä verkko-opiskelussa
}

MARKO SIITONEN \& MAARIT VALO

\begin{abstract}
Yhteisöllisyyttä korostavien, toisiaan sivuavien oppimiskäsitysten ja -teorioiden mukaan vuorovaikutus oppijoiden kesken on oppimisen edellytys. Yhteisölliseen oppimiseen on myös vahvasti liitetty opetusteknologian ja verkkoympäristöjen hyödyntäminen. Mutta kuinka tukea yhteisöllistä oppimista silloin, kun oppijat eivät ole vuorovaikutuksessa kasvokkain, vaan teknologian välityksellä? Kuinka ohjata ja edistää osallistujien vuorovaikutusta niin, että yhteistoiminnallisen oppimisen ehdot täyttyvät?
\end{abstract}

$T$ ieto- ja viestintätekniikan käyttö opetus- ja oppimistarkoituksessa on yleistynyt huomattavasti kuluneiden viidentoista vuoden aikana. Uuden teknologian myötä yhteydenpidon ja erilaisten sosiaalisten verkostojen muodot ovat monipuolistuneet. Teknologiavälitteistä vuorovaikutusta on sovellettu runsaasti myös opetuskonteksteissa. Yksilökeskeisten sovellusten lisäksi oppimista harjoitetaan teknologiavälitteisesti toimivissa ryhmissä. Teknologian käyttö oppimaan pyrkivän ryhmän apuna ei kuitenkaan ole ongelmatonta. Mahdollisuuksistaan huolimatta teknologia ei itsessään takaa tavoitteenmukaista ja toimivaa vuorovaikutusta oppijoiden välillä.

Artikkelissa tarkastellaan yhteisöllisen ja teknologiavälitteisen oppimisen suhdetta ja pohditaan, millaisin keinoin verkko-opetuksessa voitaisiin edistää oppimisen kannalta hedelmällistä vuorovaikutusta oppijoiden kesken.

Monet nykyiset oppimiskäsitykset ja -teoriat painottavat oppimisen ja opiskelun sosiaalista ja vuorovaikutuksellista luonnetta. Oppimisen tarkastelu yksilöllisenä, kognitiivisena prosessina onkin saanut rinnalleen useita yhteisöllisyyttä painottavia näkökulmia.

Yhteisöllisen oppimisen perusajatuksena on, että tietoa rakennetaan yhdessä toisten kanssa ja että oppiminen voidaan laajemminkin ymmärtää kasvamisena yhteisöllisyyteen (ks. Brown \& Renshaw 2000; Sfard 1998). Yhteistoiminnallisen oppimisen eri muotoja ja menetelmiä yhdistää ajatus siitä, että oppiminen tapahtuu oppijoiden keskinäisen neuvottelun ja ongelmanratkai- sun avulla (ks. Kumpulainen 2002). Oppimisen näkeminen osallistumisena "käytännön yhteisöjen" toimintaan (Wenger 1998) on haastanut yksilökeskeiset oppimisteoriat ja tuonut keskusteluun laaja-alaisen oppimisen käsitteen (Hakkarainen 2000). Dialogioppiminen tai kontekstuaalinen dialogioppiminen hakevat teoriaperustaa Vygotskilta ja Bahtinilta ja korostavat yksilön ja ryhmän oppimista kulttuurisessa tai organisaation kontekstissa (ks. Sarja 2000). Myös kulttuurinen oppiminen painottaa yhteisöllisen oppimisen ideaa: oppimisen perustana ovat toisten, samaan (oppimis-)kulttuuriin kuuluvien tieto ja kokemukset (Sarja 2000, 26).

Kaikkien näiden yhteisöllisyyttä korostavien, toisiaan sivuavien oppimiskäsitysten ja -teorioiden mukaan vuorovaikutus oppijoiden kesken on oppimisen edellytys. Tiedon sosiaalinen konstruoiminen tai tiedon yhteinen tuottaminen (ks. Tynjälä 1999) on mahdollista vain vuorovaikutuksessa toisten oppijoiden kanssa. Tämä näkemys on siis kaikille näille oppimiskäsityksille sama. Sen sijaan oppimiskäsitysten nimistä ja määrittelyistä on vaikea tehdä yksiselitteisiä eroja niiden välille, eikä siihen vaadittavaa käsiteanalyysiä ole mielekästä tehdä tämän artikkelin puitteissa. Selvyyden vuoksi käytämmekin ilmaisua yhteisöllinen oppiminen, kun viittaamme näitä oppimiskäsityksiä yhdistävään näkemykseen.

Sosiaalisuutta ja vuorovaikutuksellisuutta painottavien oppimiskäsitysten ohella myös tietoverkkoja hyödyntävä oppiminen on saanut 
paljon huomiota osakseen. Yhteisölliseen oppimiseen onkin vahvasti liitetty myös opetusteknologian ja verkkoympäristöjen hyödyntäminen (ks. esim. Kiviniemi 2000, Lehtinen 1997). Toki verkko-oppiminen on yksinkertaisimmillaan vain jatkoa tietoverkkoja hyödyntämättömälle etäoppimiselle, jossa painopiste on yksilössä ja jossa vuorovaikutus oppijoiden kesken on vähäistä tai olematonta. Yhä useammin verkko-oppimisessa hyödynnetään kuitenkin myös pedagogiikan sosiaalisia malleja, minkä on mahdollistanut tietotekniikan nopea kehitys viime vuosikymmenten aikana (Henri \& Rigault 1996, 4546).

Yhteisöllisen oppimisen prosessissa opettajalla on erityisen tärkeä rooli nimenomaan vuorovaikutuksen edistäjänä. Opettajan ei siis tule keskittyä vain opetuksen asiasisältöihin, vaan hänen tulisi pitää yhteisölliseen oppimiseen liittyviä sosiaalisia prosesseja keskeisenä kehittämisen kohteena (Henri \& Rigault 1996, 47-48). Tällöin tavoitteena on yhteisöllinen tiedonmuodostus sekä oppijoiden sitoutuminen ryhmän toimintaan ja oman ja muiden oppimisen edistämiseen (Kiviniemi 2000, 76-79, 98). Oppimisen vuorovaikutuksellisuuden tukeminen ja oppijoiden välisen yhteistyön synnyttäminen tuntuvat erityisen haasteellisilta nimenomaan verkkopedagogiikassa.

Verkko-oppimisen kontekstissa puhe yhteisöllisestä oppimisesta, oppimisyhteisöistä ja yhteisöllisyydestä on petollisen helppoa. Oppijoiden välinen vuorovaikutus ja yhteistyö eivät kuitenkaan ole itsestäänselvyyksiä, vaan vaativat toteutuakseen paljon työtä. Se, että kukin ryhmän jäsen käy kommentoimassa verkkokeskustelua opettajan vaatimat kolme kertaa, ei vielä tarkoita sitä, että olisi saatu aikaan laadukasta yhteisöllistä oppimista. Opettajat ovat kohdanneet sen käytännön ongelman, että oppijoita on vaikea saada oikeasti oppimaan toisiltaan. Verkkokeskusteluista tulee helposti sarja irrallisia, joskin toisiaan seuraavia, monologeja. Mistä sitten apu yhteisöllisen verkko-opetuksen suunnitteluun ja toteutukseen? Kuinka tukea yhteisöllistä oppimista silloin, kun oppijat eivät ole vuorovaikutuksessa kasvokkain vaan teknologian välityksellä? Kuinka ohjata ja edistää osallistujien vuorovaikutusta niin, että yhteistoiminnallisen oppimisen ehdot täyttyvät?

Verkko-opetusta käsitteleviä tutkimuksia on tehty jo paljon, ja niiden määrä vain kasvaa sitä mukaa kun verkko-opetus yleistyy. Tutkimus on kuitenkin pirstaloitunutta sekä lähestymistapojen, tutkimuksen kontekstin että käytössä olevan teknologian suhteen. Kärjistäen voisi esittää, että huomattava osa verkko-opetusta käsittelevästä tutkimuksesta on yksittäisten kokeilujen raportointia, joka pysyy kuvailevalla tasolla ja tiettyihin teknologisiin ratkaisuihin kiinnittyneenä. Instrumentaaliset ja teknis-taloudelliset lähestymistavat ovatkin vallitsevana suuntauksena tieto- ja viestintätekniikan opetuskäytön tutkimuksissa (Pulkkinen 2003).

Vaikka tekniikkaan on kiinnitetty paljon huomiota esimerkiksi erilaisia ryhmätyöohjelmia kehitettäessä, vaikuttavat onnistuneen verkossa työskentelyn taustalla tekniikan lisäksi konteksti, ryhmän jäsenet ja heidän ominaisuutensa, tehtävä sekä viestinnän prosessit (Scott 1999, 465). Lisäksi verkko-opetuksessa käytettävän teknologian jatkuva muutos heikentää tiettyyn tekniseen ratkaisuun keskittyvän selvityksen yleistettävyyttä.

Tarvitaankin edelleen myös yleisemmällä tasolla liikkuvaa tutkimusta, jota voidaan soveltaa monenlaisiin verkko-oppimisen konteksteihin. Yhteisöllisen ja yhteistoiminnallisen oppimisen kannalta relevantteina tutkimussuuntina näyttäytyvät yhteisötutkimus sekä ryhmäviestinnän tutkimus.

\section{Yhteisön ja yhteisöllisyyden ongelma}

Kun puhutaan yhteistoiminnallisuudesta ja yhteisöllisyydestä verkossa, on luonnollista kääntää katse ensiksi yhteisöjen ja etenkin verkkoyhteisöjen tutkimuksen puoleen. Erilaisia yhteisöjä on tutkittu kattavasti 1900-luvulla, ja verkkoyhteisöjenkin tutkimus on yleistynyt 1990-Iuvun alusta lähtien. Valitettavasti näyttää kuitenkin siltä, että yhteisötutkimus ei ole pystynyt luomaan sellaista sovellettavaa tietoa, jolla pystyttäisiin vastaamaan verkko-opetuksen käytännön ongelmiin.

Yksi yhteisötutkimuksen soveltamisen vaikeus on se, että sekä yhteisö että yhteisöllisyys näyttävät olevan liian moniselitteisiä käsitteitä tarjotakseen vakaata pohjaa opetuksen suunnittelulle. Tämä ongelma juontaa juurensa varhaiseen yhteisötutkimukseen, sillä yhteisö-käsitteen kautta on tarkasteltu niin muutaman inmisen kuin kokonaisten kansakuntienkin yhteenliittymiä (Lehtonen 1990, 9, 15). Ihmistieteiden piirissä ei 


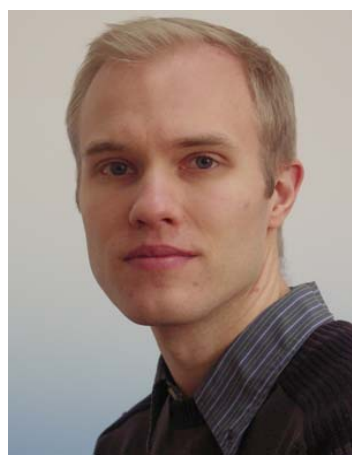

Marko Siitonen

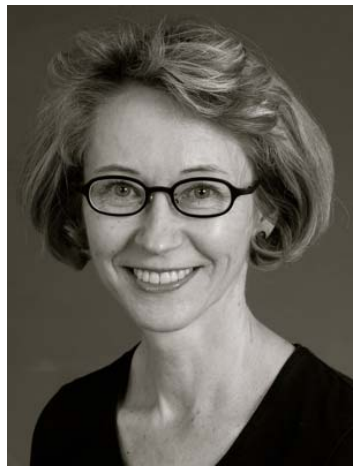

Maarit Valo olekaan yhteisymmärrystä siitä, mitkä yhteisö-käsitteen rajat ovat, vaan edelleen yhteisö joudutaan käytännössä määrittelemään uudelleen jokaista tutkimusta varten. Toisaalta yhteisötutkimusta on kritisoitu myös siitä, että se ei ole tarjonnut pohjaa tiedon kumuloitumiselle ja että sen tuottama tieto on nopeasti vanhentunut pelkiksi historiallisiksi kuriositeeteiksi (ks. esim. Brint 2001).

Tämä peruskäsitteiden epäselvyys on vaivannut myös verkoissa toimivien yhteisöjen tutkimusta (ks. esim. Jones 1995). Verkkoyhteisöiden tutkimuksessa on ollut muitakin ongelmia, joihin Castells $(2001,117)$ nimeää kolme syytä. Ensiksikin suuri osa verkkoyhteisöitä koskevasta keskustelusta ja tutkimuksesta perustuu vanhentuneeseen tietoon, joka on kerätty Internetin alkuaikoina, täysin erilaisessa sosiaalisessa ympäristössä kuin mitä nykyinen verkko edustaa. Toinen ongelma liittyy varsinaisen empiirisen datan vähäiseen määrään verkkoyhteisötutkimuksissa. Kolmantena ongelmana on Castellsin mukaan ollut keskustelun pysytteleminen yksinkertaistavalla ja ideologisella tasolla, jossa pienyhteisöjen glorifioitu menneisyys on asetettu vastakkain asosiaaliseksi ja siten pelottavaksi nähdyn tulevaisuuden kanssa.

Verkkoyhteisötutkimuksessa ei ole onnistuttu kehittämään sellaista konkreettista tietoa, joka helpottaisi verkko-opetuksen suunnittelua ja toteutusta. Verkkoyhteisötutkimukselta puuttuu vahva teoreettinen pohja, joka auttaisi suuntaamaan tutkimusta käytännön toimien kannalta hyödyllisiin päämääriin. Lisäksi yhteisöllisyyttä korostettaessa on vaarana ajautua kauas tehtäväkeskeisestä oppimiskontekstista. Vaikka yhteisöllisyys nähtäisiinkin tärkeänä oppimisen kannalta, onnistuneen oppimistilanteen takana on monia muitakin tekijöitä. Pelkkä jaettu yhteisöllisyyden tunne tai se, että oppijat viihtyvät toistensa seurassa, ei voi olla opetuksen eikä oppimisen tavoitteena.

Miksi yhteisöistä sitten edelleen puhutaan niin usein opetuksen yhteydessä? Yksi syy saattaa olla yhteisö-sanan yleispositiivinen merkitys. Eurooppalaisessa ja länsimaisessa kulttuurissa laajemminkin on kautta aikain suhtauduttu myönteisesti yhteisöihin, jopa niin, että yhteisö ja yhteisöllisyys ovat jo sanoina positiivisesti latautuneita. Etenkin arkipuheessa yhteisöihin liitetään myönteisiä mielleyhtymiä, mutta myös tieteellisessä diskurssissa yhteisöt ja yhteisöllisyys on usein nostettu itseisarvoiksi. (Ks. esim. Lehtonen 1990, 32; Saastamoinen 2001, 166.)

\section{Unohdettu ryhmänäkökulma}

Koska yhteisötutkimus ei vahvuuksistaan huolimatta kykene tukemaan yhteistoiminnallisen verkko-oppimisen kehitystyötä, on perusteltua etsiä sille vaihtoehtoja. Yksi tällainen on ryhmäviestinnän tutkimustraditio. Ryhmäviestinnän tutkimus yleistyi 1950- ja 60-luvulla, eikä se ole tähän mennessä osoittanut laantumisen merkkejä. Nimensä mukaisesti ryhmäviestinnän tutkimuksessa keskitytään ryhmän jäsenten keskinäisen vuorovaikutuksen tarkasteluun. Ryhmäviestinnän tutkimuskohteet ovat osin samankaltaisia kuin yhteisötutkimuksessa. Esimerkiksi koheesiota, yhteisiä tavoitteita ja vuorovaikutuksen merkitystä painotetaan molemmilla tutkimusaloilla.

Esitämme, että ryhmäviestinnän tutkimuksella on useita etuja verrattuna yhteisötutkimukseen silloin, kun tavoitteena on hyödyntää tutkimustietoa verkko-opetuksen suunnitteluun ja toteutukseen. Ensiksi ryhmäviestinnän tutkimus tarkastelee yhteisöä pienempää ja selvärajaisempaa inmisten joukkoa. Vaikka verkko-opetuksen keinoin onkin mahdollista saavuttaa suuria ihmismääriä, on suuri osa opetuksesta nimenomaan rajatulle oppijaryhmälle suunnattua.

Ryhmäviestinnän tutkimuksen etuna yhteisötutkimukseen verrattuna on myös se, että varsin suuri osa ryhmäviestinnän tutkimuksesta on keskittynyt erilaisiin tehtäviä suorittaviin, tavoitteellisiin ryhmiin ja niiden toimintaan vaikuttaviin tekijöihin (ks. esim. Hirokawa \& Salazar 1999). Yhteisöllinen verkko-oppiminenhan on ihanteellisesti juuri sellaista päämäärätietoista yhdessä 
oppimista, jota tavoitteelliset ryhmätkin edustavat. Täten tehtäväkeskeinen ryhmä on lähempänä verkko-opetuksen kontekstia kuin tavoitteiltaan laaja-alaisempi ja epämääräisempi yhteisö.

Kolmas argumentti ryhmäviestinnän tutkimuksen puolesta on se, että se keskittyy yhteisötutkimusta useammin määräaikaisten ryhmien toimintaan. Sen sijaan yhteisötutkimus tarkastelee sosiaalisia verkostoja pitemmällä aikavälillä. Verkko-opetuksessa päästään vain harvoin tilanteisiin, joissa oppijoilla olisi aikaa kehittyä pysyvämmäksi yhteisöksi. Yleisempää on, että oppimisryhmä kootaan tiettyä kurssia varten, jonka jälkeen ryhmä hajoaa. Ryhmänäkökulma pystyy kapeamman fokuksensa ansiosta kuvaamaan tällaista jatkuvasti muuttuvaa viestintäkontekstia paremmin kuin yhteisönäkökulma.

Jos ryhmäviestinnän tutkimus sopii niin hyvin yhteen vuorovaikutusta ja yhteisöllisyyttä painottavien oppimisnäkökulmien kanssa, miksi sen tuloksia ei ole hyödynnetty nykyistä enemmän verkossa toimivien oppijaryhmien tarkastelussa? Vielä 1950-luvulla pedagoginen lähestymistapa oli yleinen ryhmän prosesseihin keskittyvissä tutkimuksissa (Gouran, Hirokawa, McGee \& Miller 1994, 242). Sittemmin ryhmäviestinnän oman teoriapohjan kehittäminen lienee etäännyttänyt lähestymistapoja toisistaan, vaikka täytyykin muistaa, että jonkinlainen yhteys pedagogisen näkökulman ja ryhmäviestinnän tutkimuksen välillä on aina ollut. Esimerkiksi oppimiseen liittyvät kontekstit eivät ole missään vaiheessa poistuneet ryhmäviestinnän tutkimuksen kohteista, ja niitä onkin tutkittu jo usean vuosikymmenen ajan (Allen \& Plank 1999, 493).

Millaista tietoa ryhmäviestinnän tutkimus voisi tarjota? Tutkimuksessa on käsitelty ryhmäviestintätaitojen pedagogiikkaa, ryhmän tehokkaita menettelytapoja, ryhmän vuorovaikutusprosessin ominaispiirteitä, ryhmän johtajuutta sekä viestinnän ja ryhmän tuottamien tulosten välistä yhteyttä (Hirokawa, Salazar, Erbert \& Ice 1996, 360). Tutkimuksen ansiosta tiedämme paljon myös ryhmän syntymästä ja kehitysvaiheista, ryhmään osallistuvien rooleista sekä niistä vaatimuksista, joita ryhmän tehokkaalla ja tarkoituksenmukaisella toiminnalla on.

Tällaisen perustutkimuksen lisäksi ryhmäviestinnän alalta löytyy myös paljon teknologiaa hyväksikäyttävien ryhmien tutkimusta. Samaan aikaan kun pedagogiikan puolella on korostettu yhteisöllistä ja yhteistoiminnallista oppimista, on ryhmäviestintäteknologian käytön ja siihen liittyvän tutkimuksen määrä kasvanut räjähdysmäisesti (Scott 1999, 438). Nykytutkimus keskittyy mm. työyhteisöissä ja organisaatioissa toimivien, viestintäteknologian avulla työskentelevien ryhmien ja tiimien (virtuaalitiimien, hajautettujen tiimien) tarkasteluun.

Koska ryhmäviestinnän tutkimuksen laaja referoiminen ei ole mahdollista tämän artikkelin puitteissa, esitämme seuraavassa luvussa esimerkin siitä, kuinka ryhmäviestinnän tietoa voi hyödyntää verkko-opetuksen suunnittelussa ja toteutuksessa.

\section{Esimerkkinä funktionaalinen ryhmäteoria}

Yksi verkko-opetuksen ja -oppimisen kannalta hyödyllinen näkökulma ryhmäviestintään on funktionaalinen ryhmäteoria (ks. esim. Gouran \& Hirokawa 1983; 1996). Se keskittyy tarkastelemaan tehtävää suorittavan ryhmän sisäistä vuorovaikutusta ja sitä, kuinka vuorovaikutusprosessit ovat yhteydessä ryhmän päätöksenteon ja siitä seuraavan lopputuloksen laatuun. Vuorovaikutus ryhmässä ei siis ole "vain" informaation vaihdantaa, mielipiteiden ilmaisua tai ryhmähengen luomista ja ylläpitämistä, vaan se on työkalu, jolla ryhmän tavoitteet voidaan saavuttaa. Ryhmäviestinnän tarkastelu funktionaalisesta näkökulmasta korostaa ryhmän tavoitteellisuutta ja tuloksellisuutta: yhteisten tavoitteiden asettamista, tavoitteiden saavuttamisen arviointia sekä tietoista suhtautumista vuorovaikutukseen ja sen sujumiseen.

Käytännössä funktionaalinen näkökulma voi toteutua verkko-opetuksessa esimerkiksi seuraavasti. Kunkin opetuksessa muodostettavan pienryhmän annetaan itse määritellä oppimistavoitteensa, joka on kaikille ryhmän jäsenille yhteinen, niin sanottu ryhmätason tavoite. Yhteisen tavoitteen ohella ryhmän jäsenillä voi olla myös yksilöllisiä oppimistavoitteita. Lisäksi pienryhmä suunnittelee sisäisen, jäsenten keskinäisen vastuunjaon uuden tiedon konstruoimisessa. Pienryhmä tuottaa yhteistä tietoa suunnittelemansa päätöksentekoprosessin avulla, jossa edetään vaiheittain kohti yhteistä tuotosta. Tällöin jokaisen jäsenen työskentely on hyödyksi myös toisille ja jokaisen jäsenen osallistumisella vuorovaikutukseen on tunnustettu ja selkeä merkitys. Ryhmätason oppimistavoite voi olla hyvinkin 
yksinkertainen, kunhan kaikki ryhmän jäsenet ovat siihen sitoutuneet ja pyrkivät sen saavuttamiseen. Myös osa oppimisen arvioinnista voidaan antaa ryhmälle tehtäväksi, mikä lisää ryhmässä toimimisen mielekkyyttä ja tuo oppimisprosessiin uuden funktion.

Ryhmätason funktionaalinen lähestymistapa voi myös tuoda apua usein koettuun keskustelumotivaation puutteeseen verkko-opiskelussa. Tuttu tilanne verkko-opetuksessahan on se, että kurssilla käytävää keskustelua kontrolloidaan määrällisesti: jokaisen osallistujan on kommentoitava jokaista aihetta ainakin kerran, tai jokaisen osallistujan pitää kirjoittaa vähintään kolme kommenttia kurssin aikana. Viestinnän määrään liittyvät tavoitteet johtavat kuitenkin usein kakofoniaan, jossa jokainen yrittää saada äänensä kuuluviin välittämättä niinkään keskustelun sisällöstä ja joka vaimenee vasta sitten kun kaikki osallistujat ovat täyttäneet heille asetetun mitan. Vaikka määrällinenkin kontrolli voi ajoittain olla oikeutettu lähestymistapa, on kuitenkin tunnustettava, että pelkkä mielipiteiden ilmaiseminen tai edes niistä keskusteleminen ei vielä takaa motivoitumista, saati sitten oppimista.

Tietoisuus ryhmän yhteisestä tavoitteesta ja vuorovaikutusprosesseista voi auttaa verkkoopetukseen osallistujia kohti tehokkaampaa ja tarkoituksenmukaisempaa ryhmätoimintaa. Kun ymmärretään, että ryhmän toiminnan tulokset ovat kiinni jokaisen jäsenen panoksesta ja että tavoitteiden saavuttamiseen voidaan vaikuttaa tietoisesti, ollaan askel lähempänä toimivaa ryhmää. Verkko-oppimisen prosessit voivat olla lyhytaikaisia, mutta se ei ole este ryhmäytymiselle, koheesiolle eikä onnistuneelle vuorovaikutukselle. Myös hajallaan oleva verkko-oppimisryhmä voi tuntea yhteenkuuluvuutta. Onhan havaittu, että verkkoviestinnässä esimerkiksi osapuolten keskinäinen luottamus voi viestintäteknologian avulla syntyä varsin nopeasti (Marila \& Ylinen 2002).

Yhteisöllisen oppimisen tavoite ja verkkooppimisen yleistyneisyys ovat luoneet useita haasteita 2000-luvun opettajille. Tämänhetkisessä pedagogisessa keskustelussa yhteisöistä ja yhteisöllisyydestä puhuminen on syrjäyttänyt ryhmästä puhumisen. Kuitenkin oppijoiden "yhteisön" mieltäminen pienryhmäksi antaisi työkaluja opettajalle ja kouluttajalle säädellä, muokata ja rakentaa oppimiselle otollisia rakenteita. Ryhmäviestinnän tarkastelu johdattaa konkreet- tisesti oppimisryhmissä tapahtuvien ilmiöiden tarkasteluun ja lähempäänkin analyysiin. Tällaisia ryhmäilmiöitä ovat ryhmätason funktion eli tavoitteellisuuden lisäksi mm. koheesio, ryhmäidentiteetti, polarisaatio, ryhmäajattelu, päätöksentekoprosessi ja konfliktien hallinta. Ryhmäviestinnän dynamiikasta saa hyvän kuvan jo alan perusoppikirjoista (esim. Brilhart \& Galanes 1995; Hirokawa \& Poole 1996; ks. myös Ryhmäviestinnän perusteet 2002; Valkonen \& Mikkola 2000.)

Yhteisöllinen verkko-oppiminen perustuu vielä suurimmaksi osaksi tekstipohjaiseen teknologiaan. Tulevina vuosina auditiivisen ja visuaalisen viestintäkanavan tarjoava teknologia on yhä laajemmin käytössä myös oppimisessa ja opetuksessa. Monipuolistuva teknologia lisää ryhmäviestinnän ja vuorovaikutuksen mahdollisuuksia verkkokontekstissa.

\section{Kirjallisuus}

Allen, T. \& Plank, T. (1999). Group communication in the formal educational context. Teoksessa Frey, L. (toim.) The handbook of group communication theory \& research. Thousand Oaks: Sage, 493-515.

Brilhart, J. \& Galanes, G. (1995). Effective group discussion (8. painos). Madison, Wisconsin: Brown \& Benchmark Publishers.

Brint, S. (2001). Gemeinschaft revisited: A critique and reconstruction of the community concept. Sociological theory 19(1): 1-23. Haettu 7.4.2003 osoitteesta: http:// www.asanet.org/pubs/soth125.pdf.

Brown, A. J. \& Renshaw, P. D. (2000). Collective argumentation: A sociocultural approach to reframing classroom teaching and learning. Teoksessa H. Cowie \& G. van der Aalsvoort (toim.) Social Interaction in learning and instruction. Amsterdam: Pergamon, 52-66.

Castells, M. (2001). The Internet Galaxy: Reflections on the Internet, business, and society. Oxford University Press.

Gouran, D. \& Hirokawa, R. (1983). The role of communication in decision-making groups: A functional perspective. Teoksessa Mander, M. (toim.) Communications in transition. New York: Praeger, 168-185.

Gouran, D. \& Hirokawa, R. (1996). Functional 
theory and communication in decision-making and problem-solving groups: An expanded view. Teoksessa Hirokawa, R. \& Poole, M. (toim.) Communication and group decision making. 2. painos. Thousand Oaks, CA: Sage, 55-80.

Gouran, D., Hirokawa, R., McGee, M. \& Miller, L. (1994). Communication in groups: Research trends and theoretical perspectives. Teoksessa Casmir, F. (toim.) Building communication theories: A socio/cultural approach. New Jersey: Lawrence Erlbaum, 241-268.

Hakkarainen, K. (2000). Oppiminen osallistumisen prosessina. Aikuiskasvatus 20 (2), 8498.

Henri, F. \& Rigault, C. (1996). Collaborative distance learning and computer conferencing. Teoksessa Liao, T. (toim.) Advanced educational technology: Research issues and future potential. Berlin: Springer, 45-76.

Hirokawa, R. \& Poole, M. (1996). Communication and group decision making (2. painos). Thousand Oaks: Sage.

Hirokawa, R. \& Salazar, A. (1999). Task-group communication and decision-making performance. Teoksessa Frey, L. (toim.) The Handbook of group communication theory and research. Newbury Park, CA: Sage, 167-191.

Hirokawa, R., Salazar, A., Erbert, L. \& Ice, R. (1996). Small group communication. Teoksessa Salwen, M. \& Stacks, D. (toim.) An integrated approach to communication theory and research. Mahwah, NJ: Lawrence Erlbaum, 359-381.

Jones, S. (toim.1995). CyberSociety: Computermediated communication and community. Thousand Oaks: Sage.

Kiviniemi, K. (2000). Johdatus verkkopedagogiikkaan. Kokkola: Keski-Pohjanmaan ammattikorkeakoulu. Julkaisusarja A: Tutkimuksia.

Kumpulainen, K. (2002). Yhteistoiminnallinen oppiminen vertaisryhmässä: Tutkimuskatsaus. Kasvatus 33 (3), 252-265.

Lehtinen, E. (toim. 1997). Verkkopedagogiikka. Edita.

Lehtonen, H. (1990). Yhteisö. Vastapaino.

Marila, E. \& Ylinen, A. (2002). Luottamus vuo- rovaikutuksessa: Teknologiavälitteinen vuorovaikutus ja luottamuksen rakentuminen. Puheviestinnän pro gradu -tutkielma. Jyväskylän yliopisto, Viestintätieteiden laitos.

Pulkkinen, J. (2003). The paradigms of e-education: An analysis of the communication structures in the research on information and communication technology integration in education in the years 2000-2001. Kasvatustieteiden väitöskirja. Oulun yliopisto, Kasvatustieteiden ja opettajankoulutuksen yksikkö.

Ryhmäviestinnän perusteet (2002). Oppimateriaali osoitteessa: http://www.jyu.fi/viesti/ verkkotuotanto/ryhmaviesti/index.html. Viitattu 24.9.2005.

Saastamoinen, M. (2001). Elämäntapayhteisöt ja yhteisöllistämisen teknologiat identiteetti, ekspressiivisyys ja hallinnointi. Teoksessa Kuusela, P. \& Saastamoinen, M. (toim.) Ruumis, minä ja yhteisö: Sosiaalisen konstruktionismin näkökulma. Kuopion yliopisto.

SarjaA. (2000). Dialogioppiminen pienryhmässä: Opettajaksi opiskelevien harjoitteluprosessi terveydenhuollon opettajankoulutuksessa. Jyväskylän yliopisto.

Scott, C. (1999). Communication technology and group communication. Teoksessa Frey, L. (toim.) The Handbook of group communication theory and research. Newbury Park, CA: Sage, 432-472.

Sfard, A. (1998). On the two metaphors for learning and the dangers on choosing just one. Educational Researcher 27 (2), 4-13.

Tynjälä, P. (1999). Towards expert knowledge? A comparison between a constructivist and a traditional learning environment in the university. International Journal of Educational Research. 31(5), 357-442.

Valkonen, T. \& Mikkola, L. (2000). Miten analysoida tehtäväkeskeisen ryhmän vuorovaikutusta? Teoksessa Valo, M. (toim.) Nykytietoa puheviestinnän opetuksesta. Jyväskylän yliopisto, 86-108.

Wenger, E. (1998). Communities of practice: Learning, meaning, and identity. Cambridge University Press. 